\title{
Bateria-multzoen simulazio elektrotermikoak: 14S5P bateria-multzo komertziala
}

\author{
(Electrothermal simulations of battery-packs: commercial 14S5P \\ battery-pack)
}

\author{
Jose Miguel Campillo-Robles ${ }^{1 *}$, Iñaki Veci², Josu M. Igartua ${ }^{1}$, \\ Benjamín Ballesteros ${ }^{3}$ \\ ${ }^{1} \mathrm{ZTF} / \mathrm{FCT}$ (UPV/EHU) \\ ${ }^{2}$ Alten Bilbao, Derio \\ ${ }^{3}$ Muisu Fundazioa, Ermua
}

LABURPENA: Normalean ibilgailu elektriko txikietan erabiltzen den 14S5P bateria-multzoaren jokaera elektrotermikoa lehenengo aldiz aztertu dugu simulazio multifisikoen bidez. LMO kimikako 26650 bateriaren (3,5 Ah) jokaera elektrikoa simulatzeko eredu elektrokimikoa garatu dugu. LMOko katodoan NMC material aktiboa gehitu dugu (pisuan, \% 0, \% 29 eta \% 59), bateriaren ezaugarri elektrikoak hobetzen direla egiaztatzeko. LMO kimikadun 26650 bateriaren beroketa simulatu dugu intentsitate altuko deskarga batean $(10 \mathrm{~A})$, eta tenperatura \% 64 igotzen dela egiaztatu dugu. Azkenik, ohiko lan-baldintzetako korronteetan, 14S5P bateria-multzoaren tenperatura ez dela era nabarmenean handitzen frogatu dugu.

HITZ GAKOAK: modelizazioa, litio-ioiko 14S5P bateria-multzoa, 26650 bateria, LMO, hozketa pasiboa, gestio termikoa.

ABSTRACT: Electrothermal behaviour of 14S5P battery-pack, usually placed in small electric vehicles, is analysed for the first time using multiphysics simulations. An electrochemical model is developed to describe the electric behaviour of LMO 26650 battery (3.5 Ah). NMC active material is added in the LMO cathode $(0,29$, and $59 \% \mathrm{wt})$ to check the improvement of the electrical performance of the battery. The heating process of LMO 26650 battery is simulated in a high intensity discharge process $(10 \mathrm{~A})$. As a result, the temperature of the cell suffers an important increment of 64\%. Finally, with intensities of usual working conditions, the temperature of 14S5P battery-pack does not increase remarkably.

KEYWORDS: modelling, li-ion 14S5P battery-pack, 26650 battery, LMO, passive cooling, thermal management.

\footnotetext{
* Harremanetan jartzeko / Corresponding author: Jose Miguel Campillo-Robles, Fisika Aplikatua II saila, Zientzia eta Teknologia Fakultatea (UPV/EHU), Sarriena auzoa z/g, 48940, Leioa, Euskal Herria. - joxemi.campillo@ehu.eus - https://orcid. org/0000-0002-2565-6343.

Nola aipatu / How to cite: Campillo-Robles, Jose Miguel; Veci, Iñaki; Igartua, Josu M.; Ballesteros, Benjamín (2020). "Bateria-multzoen simulazio elektrotermikoak: 14S5P bateria-multzo komertziala»; Ekaia, 37, 2020, 271-289. (https://doi.org/10.1387/ekaia.20844).

Jasoa: 15 maiatza, 2019; Onartua: 21 urria, 2019.

ISSN 0214-9001 - eISSN 2444-3255 / (c) 2020 UPV/EHU
}

cc)(i) () Obra hau Creative Commons Atribución 4.0 Internacional-en lizentziapean dago 


\section{SARRERA}

XIX. mendearen hasieran, lehenengo kotxe elektriko txikiak eraikitzen hasi ziren Hungarian, Herbehereetan eta AEBtan [1,2]. Ordutik hona, mota askotako saiakerak egin dira ibilgailu elektrikoak gizarteratzeko, baina guztiek arrakastarik gabe amaitu dute. Azken garaietan, kutsadura, klima-aldaketa, petrolioaren gailurra eta bestelako arazoak direla medio, barne-errekuntzako motorrak baztertzeko beharra areagotu da [3, 4]. Gauzak horrela, hurrengo urteetan mota askotako ibilgailu elektrikoak nagusituko dira gure hirietako kale eta errepideetan: txirringa elektrikoak, bus elektrikoak, patinete elektrikoak, kotxe elektrikoak eta abar. Momentu honetan, adibidez, gehien zabalduta dagoen ibilgailu elektrikoa da txirringa elektrikoa, batik bat, Asian daukan erabileragatik (ikus 1. irudia).

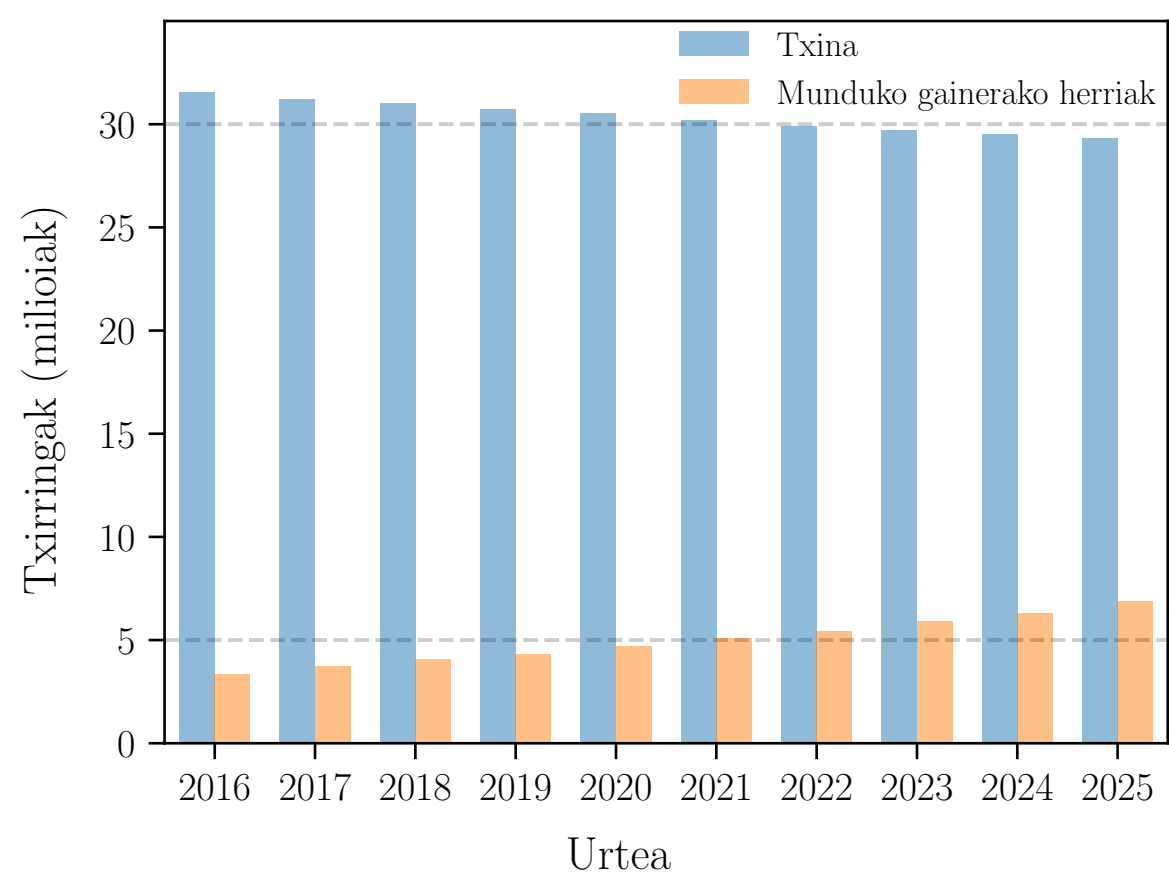

1. irudia. Txirringa elektrikoen salmenta-aurreikuspena munduan [5].

Aldi berean, munduko energia-eskaera etengabe handitzen ari da eta gizartearen eguneroko ohiturak aldatzen ari dira. Horren eraginez, transformazio garrantzitsuak gertatzen ari dira energia-sektorean [6]. Adibidez, azken urteetan metagailu elektrokimikoen erabilera areagotu da, gehienbat bateria sekundarioena. Gaur egun, esaterako, litio-ioi bateriak nonahi daude 
gure bizitzan, eguneroko tresna elektriko eramangarri gehienak elikatzen baitituzte: telefono adimendunak, erlojuak, tabletak, etxetresna elektrikoak, GPS gailuak, ordenagailu eramangarriak eta abar [7]. Are gehiago, litio-ioi bateriak gure auzoak, etxeak eta ibilgailuak ere elektrikoki elikatzen hasi dira jadanik [8].

Litio-ioi bateria mota asko dago, eta horiek sailkatzeko hainbat irizpide har daitezke kontutan. Normalean, katodoan erabiltzen den material aktiboaren arabera sailkatu ohi dira halako bateriak [9]. Askotan, material aktiboaren formula kimikoa erabiltzen da bateria izendatzeko, eta beste batzuetan, berriz, elementu kimikoen izendapenetik eratorritako sigla (ikus 1. taula).

1. taula. Litio-ioi baterietan erabili ohi diren material aktiboen ezauga$\operatorname{rriak}[10,11]$.

\begin{tabular}{lllccc}
\hline \multicolumn{1}{c}{ Katodoa } & Izendapena & Egitura & $\begin{array}{c}\text { Batez besteko } \\
\text { potentziala } \\
\left(\mathrm{vs} \mathrm{Li} / \mathrm{Li}^{+}\right)(\mathrm{V})\end{array}$ & $\begin{array}{c}\text { Kapazitate } \\
\text { espezifiko } \\
\text { teorikoa } \\
\left(\mathrm{mAh} \mathrm{g}^{-1}\right)\end{array}$ & $\begin{array}{c}\text { Deskargaturiko } \\
\text { kapazitate } \\
\text { espezifiko erreala } \\
\left(\mathrm{mAh} \mathrm{g}^{-1}\right)\end{array}$ \\
\hline $\mathrm{LiFePO}_{4}$ & LFP & Olibinoa (1D) & 3,45 & 170 & $\sim 160$ \\
$\mathrm{LiCoO}_{2}$ & $\mathrm{LCO}$ & Geruzatua (2D) & 3,9 & 274 & $\sim 140$ \\
$\mathrm{LiNi}_{1 / 3} \mathrm{Mn}_{1 / 3} \mathrm{Co}_{1 / 3} \mathrm{O}_{2}$ & $\mathrm{NMC}, \mathrm{NCM}$ & Geruzatua (2D) & 3,8 & 278 & $\sim 170$ \\
$\mathrm{LiNi}_{0,8} \mathrm{Co}_{0,15} \mathrm{Al}_{0,05} \mathrm{O}_{2}$ & $\mathrm{NCA}$ & Geruzatua (2D) & 3,8 & 265 & $\sim 200$ \\
$\mathrm{LiMn}_{2} \mathrm{O}_{4}$ & $\mathrm{LMO}, \mathrm{IMR}$ & Espinela (3D) & 4,1 & 148 & $\sim 120$ \\
\hline
\end{tabular}

Erabilerari dagokionez, litio-ioi baterien iraupena, eraginkortasuna eta segurtasuna beren lan-baldintzen araberakoa izaten da, eta, gehienbat, beren lan-tenperaturak mugatzen du. Izatez, bateria guztien funtzionamendu eraginkorra bermatzeko tenperatura kontrolatu behar da, eta hori askoz garrantzitsuagoa da litio-ioi baterietan [12]. Tenperatura baxuetan, bateriaren kapazitatea txikitzen da, barne-erresistentzia handitzen da, eta gainera, anodoan litio-deposizioa gertatzeko arriskua handitzen da. Tenperatura altuetan, aldiz, bateriaren zahartze-prozesuak areagotzen dira, eta eraginkortasuna txikitzen da. Tenperaturaren kudeaketa egokirako, bateriek berek askatzen duten beroa ere kontutan hartu behar da. Izan ere, bateria guztien erabileran beroa askatzen da hainbat arrazoirengatik: erreakzio elektrokimikoak, Joule efektua eta elektrodoetan gertatzen diren beste fenomeno itzulgarri eta itzulezinak. Barne-beroketa kontrolik gabe gertatzen denean (adibidez, bateriaren tenperatura minutuko $10{ }^{\circ} \mathrm{C}$ baino gehiago handitzen bada), arrisku handiko egoera sortu daiteke. Hain zuzen ere, litio-ioi baterien energia-dentsitatea ohiko leherkarienaren \% 20 ingurukoa izan ohi da, 
Jose Miguel Campillo-Robles, Iñaki Veci, Josu M. Igartua, Benjamín Ballesteros

eta kate-erreakzioa gerta daiteke. Berez, gaur egun, litio-ioi bateria komertzialak -20 eta $60^{\circ} \mathrm{C}$ artean lan egiteko gai dira [13]. Hala ere, litio-ioi baterien tenperatura 5 eta $40{ }^{\circ} \mathrm{C}$ artean mantentzea gomendatzen da edozein lan-baldintzatarako [13].

Normalean, bateriak ez dira banaka erabiltzen, hainbat elkarketa moten bitartez batzen dira bateria-multzo deritzenak sortzeko. Bateria-multzo horien lan-tenperatura era egokian kontrolatzea oso garrantzitsua da. Hori dela eta, baterien artean 3 eta $5{ }^{\circ} \mathrm{C}$-ko tenperatura-diferentzia ez gainditzea aholkatzen da $[13,14]$. Ikerketa-lan honetan, 14S5P bateria-multzo komertzialaren lehenengo azterketa elektrotermikoa burutu dugu elementu finituen bidezko kalkulu multifisikoen bitartez. Horretarako, ikerketa hiru ataletan banatu dugu. Hasteko, 26650 formatuko LMOko bateriarako eredu elektrokimikoa garatu dugu, bateriaren jokaera elektrikoa deskribatzeko. Ondoren, LMO kimikadun katodoan, NMC material aktiboa sartzeak bateriaren jokaera elektrikoan duen efektua teorikoki aztertu dugu. Jarraian, 26650 formatuko bateriaren eredu elektrotermikoa prestatu dugu, termikoki nola portatzen den ikusteko. Azkenik, 14S5P bateria-multzo komertzialaren eredu elektrotermikoa garatu dugu, ohiko lan-baldintzetan erakusten duen jokaera termikoa aztertzeko eta bere diseinuaren egokitasuna ziurtatzeko.

\section{BATERIEN MODELIZAZIO MULTIFISIKOA}

Gaur egun, bateria-multzoen diseinu-prozesua asko erraztu eta azkartu da zenbakizko metodoetako simulazio multifisikoei esker. Bateria-multzoen simulazioetan, efektu elektriko eta termikoak aldi berean analizatu nahi izaten dira, uztartutako eredua deiturikoa erabiliz [15]. Horretarako, 2. irudiak erakusten duen moduan, bi urratsetan banatu behar da simulazioa. Lehenbizi, bateriaren ezaugarriak definitu behar dira, bateriaren eredu elektrokimikoa garatzeko. Bateriaren ezaugarri geometrikoak finkatzeaz gain, berau osatzen duten materialen ezaugarri fisiko eta elektrokimikoak ere finkatu behar dira. Eredu elektrokimiko honen bitartez, bateriaren barne-prozesu elektrokimikoak azter ditzakegu maila mikroskopikoan. Are gehiago, ereduak bateriaren maila makroskopikoko jokaera elektrikoa ere deskribatuko du. Ondoren, bateria-multzoaren eredu multifisikoa garatu behar da, efektu elektrikoak eta termikoak uztartuz. Horretarako, baterien banaketa geometrikoa finkatu behar da, eta inguruko materialak definitu (adibidez, airea eta bateria-multzoaren karkasa). Bateria-multzoaren lanbaldintzak eta sistemaren muga-baldintzak finkatu ondoren, prozesu fisiko eta kimiko guztiak aldi berean simulatzen dira.

Litio-ioi baterien jokaera elektriko eta termikoen modelizazio eta simulazioetarako, zenbakizko metodoetako hainbat software komertzial erabil- 
tzen dira. Zalantzarik gabe, Siemens konpainiak garatutako Battery Design Studio $^{\circledR}$ (BDS) eta STAR CCM+/Battery Simulation Module ${ }^{\mathrm{TM}}$ (BSM) programak dira erabilienak. Izan ere, programa hauen bidez erraztasunez simula daitezke aplikazio industrialetako bateria-multzoen jokaera [16], eta horregatik, beste batzuen artean autogintza-sektoreko enpresa askotan erabiltzen dituzte.

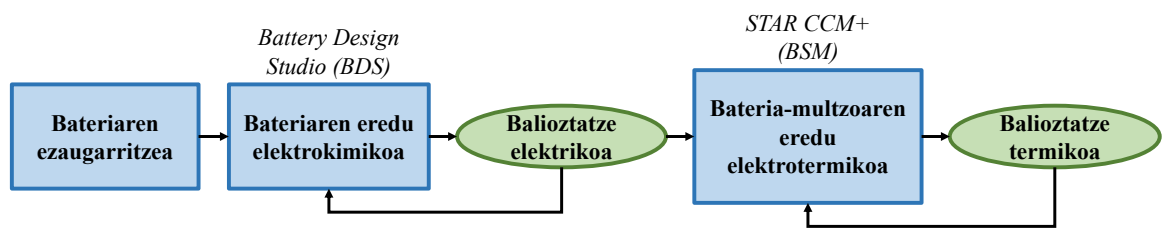

2. irudia. Bateria-multzoaren analisi termikoaren fluxu-diagrama.

\section{14S5P BATERIA-MULTZOA}

Triziklo elektrikoa da Evolo Z2 [17], eta hirietan zama txikiak banatzeko diseinaturik dago (ikus 3. irudia). Txirringa elektrikotzat har daiteke Evolo Z2. Izan ere, 2002/24/CE Europako Zuzentaraua [18] eta ISO 4210:1996 araua [19] betetzen ditu. Arautegi hauen arabera, honako ezaugarri hauek izan behar ditu txirringa elektrikoak: bi edo hiru gurpil, motorraren gehienezko potentzia $250 \mathrm{~W}$, eta motorra gelditu behar da hiru kasu hauetan: $25 \mathrm{~km} \mathrm{~h}^{-1}$-ko abiadura gainditzean, pedalei eragiten ez zaienean eta balaztatzen denean. Hiru ezaugarri horiek betetzen baditu, ibilgailuak txirringa arrunt baten abantailak izango ditu, hau da, gidabaimenik eta segururik ez behar izatea, txirringa-bideak erabili ahal izatea eta hirien barruan kaskorik gabe erabili ahal izatea (udalerri batzuetan izan ezik). Evolo Z2 trizikloa 14S5P bateria-multzo komertzialarekin elikatzen da.

Baterien hainbat formatu erabili daitezke bateria-multzoak eraikitzeko [20]: zilindrikoa, prismatikoa, coin eta pouch. Bateria-multzoen ekoizleek merkatuan dauden bateria-formatuen artean aukeratzen dute beren interesen edo aplikazioaren arabera. Ibilgailu elektrikoetan, adibidez, tamaina handiko bateria prismatikoak edo pouch motakoak erabiltzen dituzte ekoizle gehienek. Tesla enpresak, aldiz, txikiagoak diren bateria zilindrikoen aldeko apustua egin du. Izan ere, formatu zilindrikoko bateriak merkeagoak izaten dira prismatikoa eta pouch motakoak baino. Hala ere, bateria-multzoa kudeatzeko sistema sofistikatuagoa (ingelesez, Battery Management System, BMS) behar izaten dute bateria zilindrikoek. 


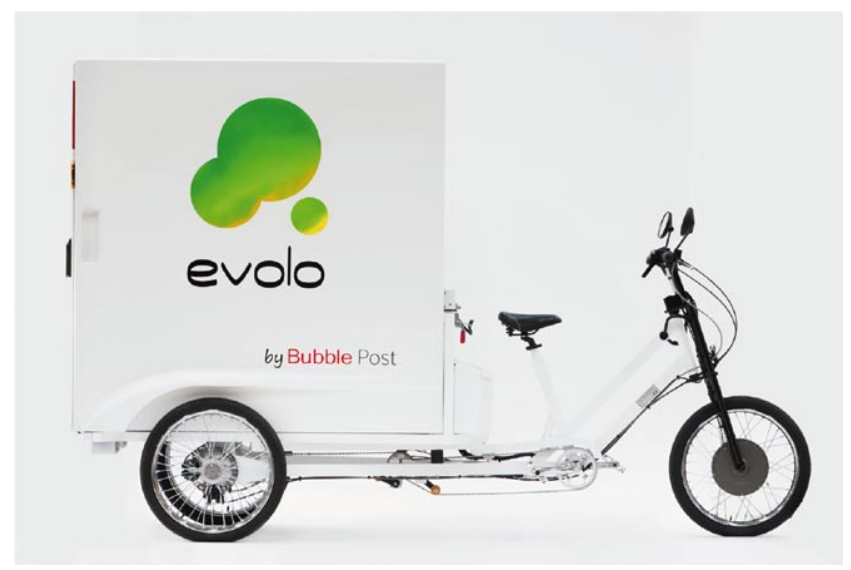

3. irudia. Evolo Z2 triziklo elektrikoa. Eserlekuaren azpiko gordailuan dago 14S5P bateria-multzoa.

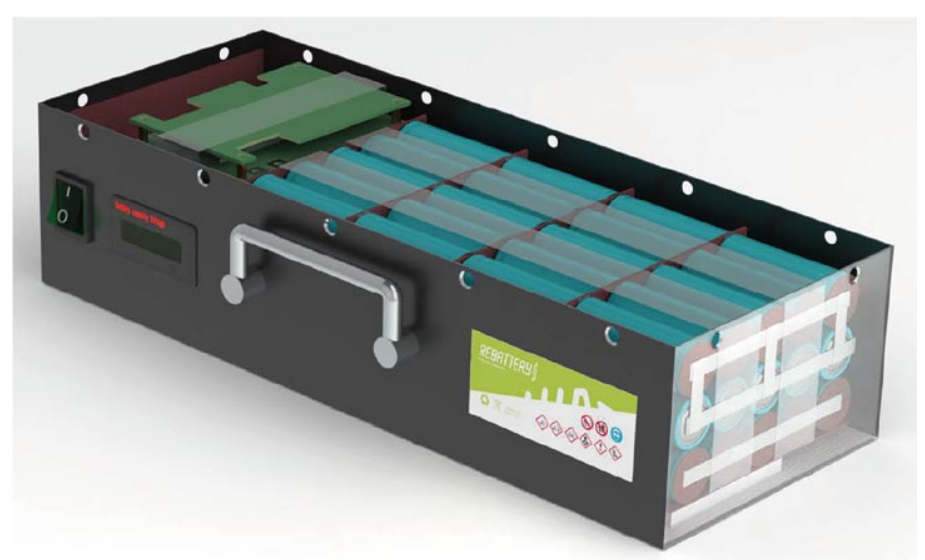

4. irudia. Rebattery enpresako 14 S5P bateria-multzoaren geometria eta barne-banaketa.

14S5P bateria-multzoa oso zabalduta dago merkatuan, batik bat txirringa elektrikoak elikatzeko [21]. 14S5P kodeak honako hau adierazi nahi du: (5P) 5 paraleloan eta (14S) 14 seriean. Hau da, bateria-multzo honek paraleloan kokaturiko 5 bateriarekin osatutako 14 multzo dauzka seriean jarrita (ikus 4. irudia). BMS delakoa ere bateria-multzoa babesten duen karkasa metaliko itxiaren barruan dago. Baterien konfigurazioa dela eta, 14S5P bateria-multzoak ematen duen tentsio nominala bateria batena baino 14 aldiz handiagoa da. Bestalde, 70 bateriatan $(14 \times 5=70)$ pilatu 
daitekeen energia bateria batena baino 70 aldiz handiagoa izan arren, bateria-multzoaren kapazitatea Ah-tan bateria batena baino 5 aldiz handiagoa baino ez da. Txirringa elektrikoetan erabiltzen diren 14S5P bateria-multzoek 18650 formatuko bateriak erabili ohi dituzte $(18 \mathrm{~mm}$-ko diametrodunak eta $65,0 \mathrm{~mm}$-ko altueradunak) [15] eta, orotara, bateriamultzo osoak (karkasa eta guzti) $5 \mathrm{~kg}$-ko masa izan ohi du. Zama txikia denez, bizikletatik kendu eta kargatzera etxera eraman daitezke horrelako bateria-multzoak. Merkatuan, 26650 formatuko bateriekin eraikitako 14S5P bateria-multzoak ere badaude (26 mm-ko diametrodunak eta 65,0 mm-ko altueradunak) [15], adibidez, Rebattery enpresak Evolo Z2 triziklorako diseinaturikoak (ikus 3. eta 4. irudiak). Horrelako bateriamultzoak pisutsuagoak izaten dira (10 kg inguru), baina oraindik ere eramangarriak dira.

2. taulak litio-ioi bateria komertzialak kimikaren arabera sailkatzen ditu, eta beren ezaugarri garrantzitsu batzuk aipatzen ditu. Normalean, 14S5P bateria-multzoa NMC kimikako bateriekin eraiki ohi da, gehienbat LFP eta litio titanatoko (anodoa: $\mathrm{Li}_{4} \mathrm{Ti}_{5} \mathrm{O}_{12}$, LTO eta katodoa: LFP, NCA...), bateriekin eraikitakoa baino merkeagoa delako. Seriean dauden $14 \mathrm{NMC}$ bateriekin 53,2 V-eko tentsio nominala lortu ohi da. Hori nahikoa da ibilgailu elektriko txikiak higiarazteko erabiltzen diren motor elektrikoak elika daitezen (tentsio nominala $\sim 48 \mathrm{~V}$ ). Baterien kimika aldatuko bagenu, bateria-multzoaren tentsioa ere aldatuko litzateke. Adibidez, Teslak erabiltzen duen NCA kimikadun bateriekin 50,4 V lortuko genuke, eta LFP kimikakoekin, aldiz, 46,2 V (ikus 2. taula). Azken horrekin lortzen den tentsioa ez da nahikoa motor elektrikoari era egokian eragiteko. Hori dela eta, LFP-ko bateria-multzoaren konfigurazioa 15S5P egiturara aldatu ohi da, 49,5 V-eko tentsioa lortzeko.

2. taula. Litio-ioi bateria komertzialen ohiko ezaugarriak [22].

\begin{tabular}{|c|c|c|c|c|c|c|}
\hline \multicolumn{2}{|c|}{ Kimika } & \multirow{2}{*}{ Noiztik } & \multirow{2}{*}{$\begin{array}{c}\text { Tentsio } \\
\text { nominala } \\
(\mathrm{V})\end{array}$} & \multirow{2}{*}{$\begin{array}{c}\text { Energia } \\
\text { espezifikoa } \\
\left(\mathrm{Wh} \mathrm{kg}^{-1}\right)\end{array}$} & \multirow{2}{*}{ Zikloak } & \multirow{2}{*}{$\begin{array}{c}\text { Ihes-tenperatura } \\
\left({ }^{\circ} \mathrm{C}\right)\end{array}$} \\
\hline Anodoa & Katodoa & & & & & \\
\hline Grafitoa & LCO & 1991 & $3,7 \sim 3,9$ & $150 \sim 200$ & $500 \sim 1.000$ & 150 \\
\hline Grafitoa & LMO & 1996 & $3,7 \sim 4,0$ & $100 \sim 150$ & $300 \sim 700$ & 250 \\
\hline Grafitoa & $\mathrm{NMC}, \mathrm{NCM}$ & 2008 & $3,8 \sim 4,0$ & $150 \sim 220$ & $1.000 \sim 2.000$ & 210 \\
\hline Grafitoa & LFP & 1993 & $3,2 \sim 3,3$ & $90 \sim 130$ & $1.000 \sim 2.000$ & 270 \\
\hline Grafitoa & NCA & 1999 & $3,6 \sim 3,65$ & $200 \sim 260$ & 500 & 150 \\
\hline LTO & $\mathrm{NCA}$ & 2008 & $2,3 \sim 2,5$ & $70 \sim 85$ & $3.000 \sim 7.000$ & - \\
\hline
\end{tabular}


Ikerketa-lan honetan, MNKE 26650 (3.500 mAh) bateriekin eraikitako 14S5P bateria-multzoa aztertuko dugu. 26650 bateria hau LMO kimikakoa da. 1983. urtean proposatu zen lehen aldiz LMOko kimika litio-ioi baterien katodoetarako [23]. LMOko material aktiboak potentzial altua dauka, 4,1 V (vs $\mathrm{Li} / \mathrm{Li}^{+}$), baina bere kapazitate teorikoa eta praktikoa baxuak dira (ikus 1. taula): 148 eta $120 \mathrm{mAh} \mathrm{g}^{-1}$ hurrenez hurren [10]. 1996an merkaturatu zen lehenengo aldiz LMOko material aktiboa bateria komertzial baten katodoan [24]. Gaur egun, ibilgailu elektriko batzuen bateria-multzoak eraikitzeko erabiltzen ari da (adibidez, Nissan Leaf, Chevrolet Volt, Renault Zoe eta abar). LMO termikoki oso egonkorra da, eta barne-erresistentzia txikia dauka, intentsitate altuko deskargak ahalbidetuz. Tamalez, LMOk lan-bizitza laburra dauka, eta bere kapazitatea, beste kimikekin alderatuta, txikia da (ikus 1. eta 2. taulak). Arazo horiek saihesteko, LMOko material aktiboari NMC gehitzen diote ekoizle gehienek, kapazitatea handitzeko eta bizitza luzatzeko [25-28]. Horregatik, gaur egun, merkatuan ia ez dago LMO hutsezko bateriarik.

\section{26650 FORMATUKO BATERIAREN SIMULAZIO ELEKTROKIMIKOA}

Esan bezala, bateria-multzoa modelizatu aurretik berau osatzen duten baterietako bat modelizatu behar da bere jokaera elektrikoa era egokian deskribatzeko. Lehenbizi, bateriaren ezaugarriak zehaztu behar dira: parametro geometrikoak, materialen proportzioak, ezaugarri fisikoak eta elektrokimikoak eta abar. Ekoizleek horrelako datuak konpartitzen ez dituztenez, datuak ezagutzeko ezinbestez zabaldu eta ezaugarritu behar da bateria. Zoritxarrez, horrek baliabide eta denbora asko eskatzen ditu, eta, horrenbestez, gehienetan, beste ikertzaileek bibliografian plazaratutako datuak erabiltzen dira. Ikerketa honetan, MNKE 26650 (3.500 mAh) bateriaren simulazioa gauzatzeko behar diren parametro guztiak bibliografiatik lortu ditugu $[29,30]$ (ikus 3. taula).

3. taula. 26650 formatuko LMOko bateriaren ezaugarri garrantzitsu batzuk [29, 30].

\begin{tabular}{lcc}
\hline & Anodoa & Katodoa \\
\hline Material aktiboa (pisua, \%) & 95 (grafitoa) & $89(\mathrm{LMO})$ \\
Bestelakoak (pisua, \%): & 5 & 5 \\
- Aglutinatzailea & - & 6 \\
- Karbono beltza & 55 & 87 \\
\hline Alde bakarreko estaldura $(\mu \mathrm{m})$ & 0,262 & 0,267 \\
\hline Porositatea
\end{tabular}


Bibliografiatik lortutako ezaugarriak Battery Design Studio ${ }^{\circledR}$ softwarean inplementatu ditugu, eta elektrodoen luzera doitu dugu MNKE 26650 (3.500 mAh) bateriaren kapazitatea lortzeko. Gauzak horrela, 4. taulako bigarren zutabean ageri diren ezaugarri elektrikoak lortu ditugu simulatutako bateriarako. Gure emaitzak MNKE 26650 (3.500 mAh) bateriaren fitxa teknikoaren datuekin alderatu ditugu [31], eta tentsio nominala \% 6 altuagoa lortu dugu. Merkatuan, LMO kimikako baterien material aktiboan NMC sartzen ari dela jakitun [25-28], katodoan LMOko proportzioa $\%$ 60ra eta \% 30era jaitsi dugu (LMO60 eta LMO30) bere lekuan NMC sartzeko (ikus 4. taula). Simulazioetan erabili ditugun NMC materialaren propietateak BDS softwareko datu-basekoak dira, NMC111 materialekoak alegia. Katodoaren konposizio-aldaketa horren ondorioz, bateriaren kapazitatea nabarmen handitu da, eta tentsio nominala jaitsi da. Tentsioaren bilakaera honek iradokitzen du MNKE 26650 (3.500 mAh) bateria komertzialean NMC egon litekeela katodoaren material aktiboan.

4. taula. NMCren ehunekoaren efektua bateriaren ezaugarri elektrikoetan (simulazioetako emaitzak). "Karga-egoera \% 50 denean, bateriak daukan tentsioa da tentsio nominala.

\begin{tabular}{lccc}
\hline & LMO & LMO60 & LMO30 \\
\hline \multicolumn{1}{c}{ Katodoa } & & & \\
LMO (pisua, \%) & 89 & 60 & 30 \\
NMC (pisua, \%) & 0 & 29 & 59 \\
Bestelakoak (pisua, \%) & 11 & 11 & 11 \\
\hline Kapazitate-ratioa ${ }_{\text {anodo/katodo }}$ & 1,220 & 0,848 & 0,638 \\
\hline Tentsio nominala* (V) & 3,91 & 3,83 & 3,76 \\
\hline Kapazitatea (Ah) & 3,48 & 3,98 & 4,40 \\
\hline Dentsitate energetikoa: & & & \\
$\quad\left(\right.$ Wh L $\left.{ }^{-1}\right)$ & 399 & 442 & 479 \\
$\quad\left(\right.$ kg k $\left.^{-1}\right)$ & 153 & 168 & 180 \\
\hline
\end{tabular}

Sortutako bateria berri biak, LMO60 eta LMO30 alegia, desorekatuta daude, katodoa gaindimentsionatua daukatelako. Berez, anodo eta katodoaren arteko kapazitate-ratioa 1,1 eta 1,2 artean egon behar da [32]. Tarte horren azpitik badago, LMO60 eta LMO30 baterien kasuan bezala (ikus 4. taula), anodoan litio-estalketa gertatzeko arriskua areagotzen da. Hori ekiditeko, katodoaren estaldura-lodiera txikitu beharko litzateke. Hori egitean, LMO60 eta LMO30 bateriak orekatuko genituzke, eta, gainera, energia-dentsitatea 4. taulakoarekin alderatuta, are gehiago handituko litzateke. 
Hortaz, orekatutako LMO60 eta LMO30 baterien ezaugarriak LMO bateriarenak baino hobeak lirateke.

LMO, LMO60 eta LMO30 baterien erantzun elektrikoa egiaztatzeko, deskargatutako kapazitatearekin tentsioa nola aldatzen den aztertu dugu. Horretarako, guztiz kargatutako baterietan $\mathrm{C}$ eta $\mathrm{C} / 2$ deskarga-prozesuak simulatu ditugu (ikus 5. irudia). Katodoen osaketa kimikoaren eragina nabarmen ikusten da deskargetako parametro batzuetan. Adibidez, hiru baterien artean, LMO30 bateriak eskaintzen du deskarga-kapazitaterik handiena, NMC ehuneko altuagoa edukitzeagatik. Hala ere, tentsioaren bilakaera nahiko antzekoa da hiru kasuetan (ikus 5. irudia). Hots, katodoaren osaketa kimikoak ez du aldaketa nabarmenik sortzen tentsioaren jaitsieran. Beste aldetik, $\mathrm{C}$ deskargan hiru baterien tentsioa txikiagoa da, polarizazioa altuagoa delako. Dena dela, hiru baterietan deskargatutako kapazitatea antzekoa da bi deskarga-abiaduretan. Hau da, Peukert-en efektua ez da agerian geratzen, intentsitateen arteko diferentzia txikia delako. Izan ere, Peukerten efektua lege enpiriko bat da deskarga-intentsitatea eta deskargakapazitatea erlazionatzeko [33, 34]. Horrela, Peukerten legeak kuantitatiboki deskribatzen du deskarga-intentsitatea handitzean deskargaturiko kapazitatea nola txikitzen den.

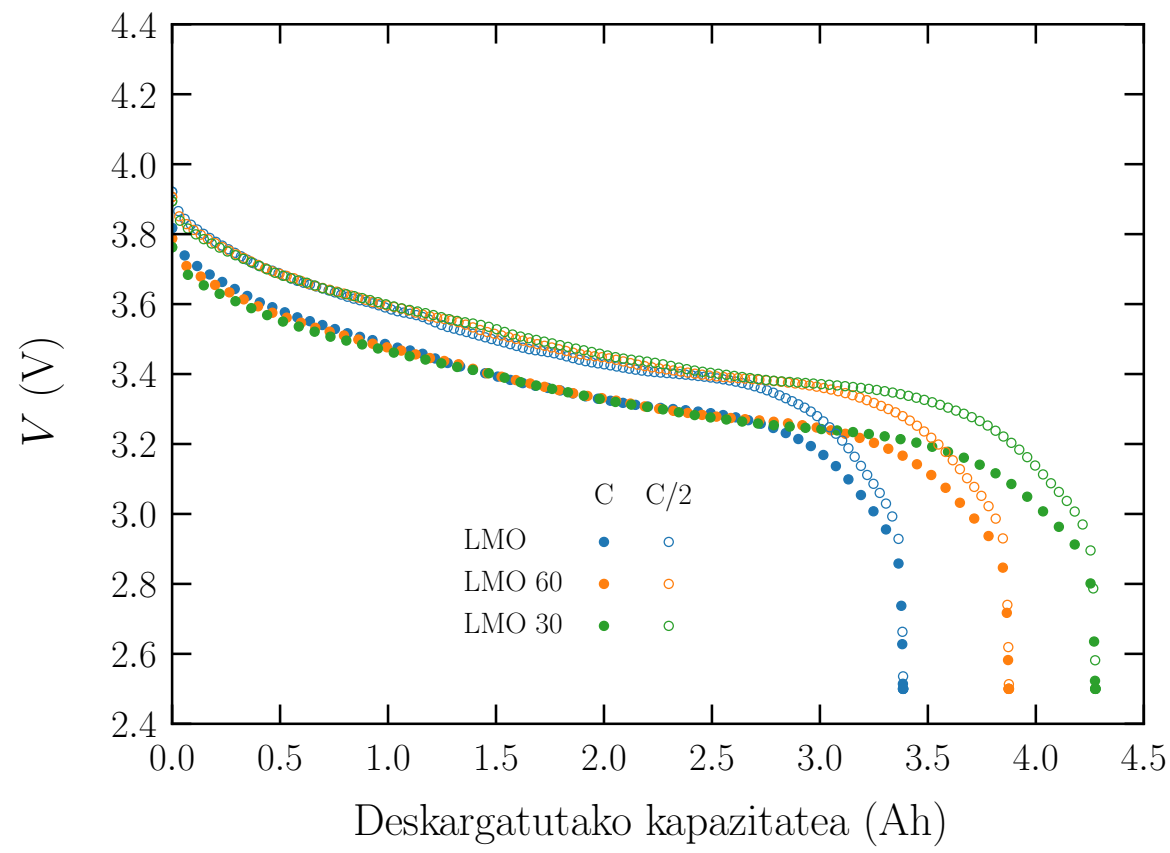

5. irudia. LMO, LMO60 eta LMO30 baterietako tentsioaren bilakaera deskargaprozesuetan $(\mathrm{C}$ eta $\mathrm{C} / 2)$. 
6 irudiak gauza bera erakusten digu baterien karga-prozesuetarako, eta ondorio berdinak azpimarratu daitezke kasu honetan ere.

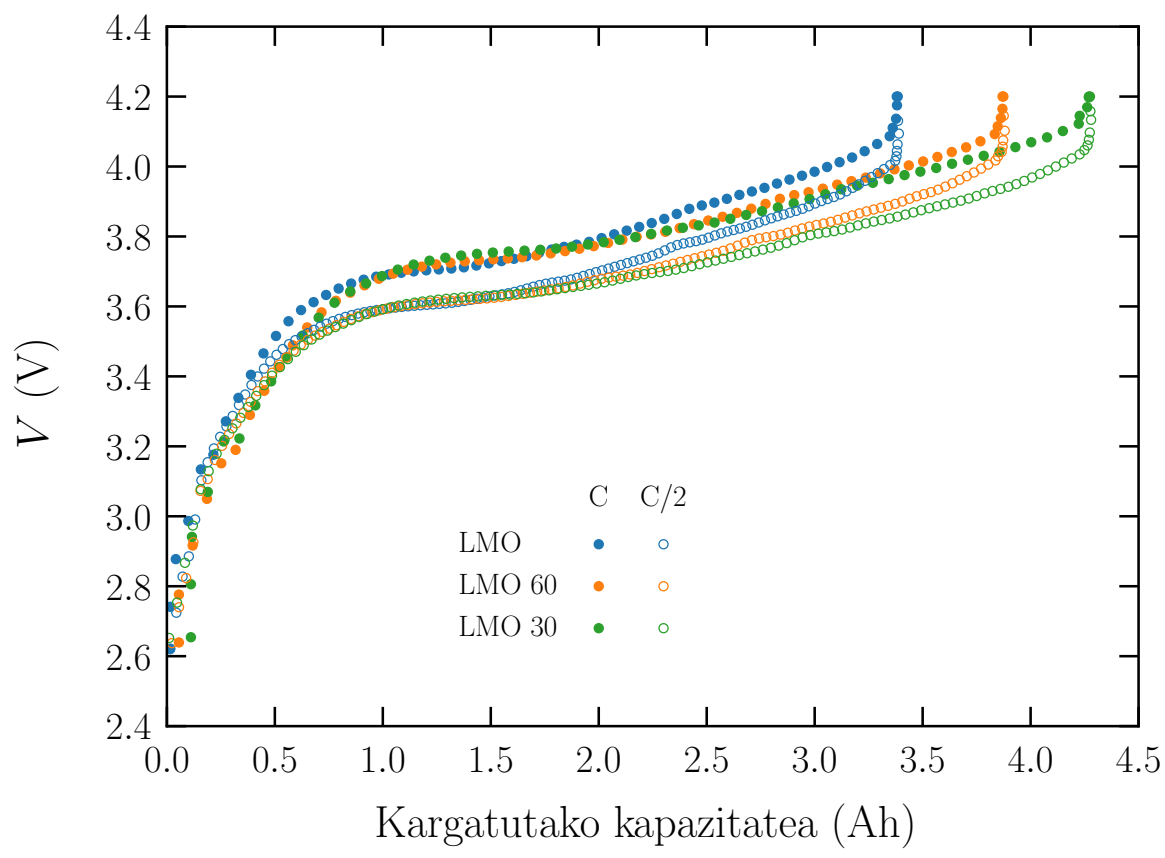

6. irudia. LMO, LMO60 eta LMO30 baterietako tentsioaren bilakaera kargaprozesuetan $(\mathrm{C}$ eta $\mathrm{C} / 2)$.

\section{SIMULAZIO ELEKTROTERMIKOAK}

Bateria-multzoaren jokaera elektrotermikoa aztertzeko STAR CCM+ ${ }^{\mathrm{TM}}$ programaren BSM modulua erabili dugu. Bolumen Finituen Metodoa (ingelesez, Finite Volumen Method, FVM) erabiltzen du STAR CCM+ ${ }^{\mathrm{TM}}$ programak simulazio multifisikoak burutzeko.

Hasteko, Battery Design Studio ${ }^{\circledR}$ programan sortutako bateria hartu behar da, eta bateria-multzoaren banaketa espaziala sortu behar da. Baterien arteko lotura elektrikoak, BMSa, karkasa eta bestelako elementuak simulazioan sartzeko aukera dago, baina ez da beharrezkoa (bilatzen dugun simulazioaren konplexutasunaren araberakoa baita hori). Jarraian, bateriamultzoaren eskualde guztiak bolumen txikietan banatzen dira, gelaxkak, alegia. Gelaxka hauek nodoak deituriko puntuen bidez lotuta daude. STAR $\mathrm{CCM}+{ }^{\mathrm{TM}}$ programak bi sare sortzen ditu, bata soluzio elektrikoa kalkulatzeko eta bestea soluzio termikorako. Bolumenak saretu ostean, bate- 
ria-multzoaren borneetan zirkuitu elektrikoa konektatzen da prozesu elektrikoak eragiteko. Azkenean, simulazioa burutzean, kalkulu elektriko eta termikoak uztartzen dira, eta soluzio autobateragarria metodo iteratibo baten bidez lortzen da.

\subsection{LMO kimikadun 26650 bateria}

Analisi elektrotermikoa hasteko, LMO kimikadun 26650 bateria aztertu dugu. Bateria zilindrikoa 37.364 gelaxketan banatu dugu zenbakizko kalkulua burutzeko (ikus 7. irudia).

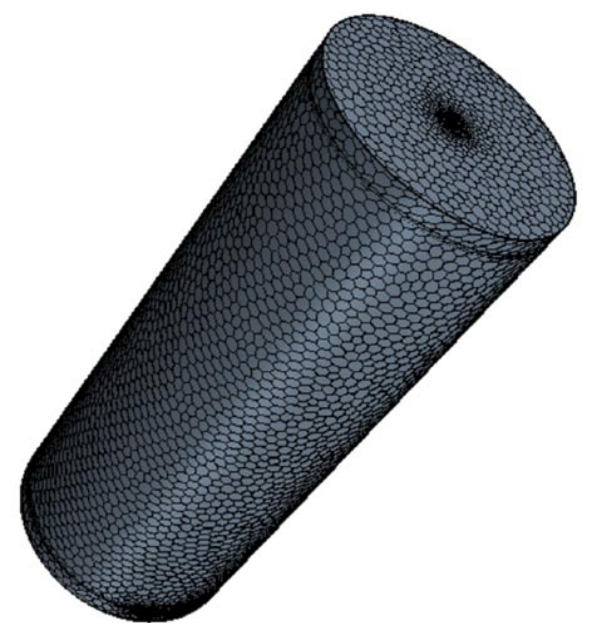

7. irudia. 26650 bateriaren kalkulu-sarea.

Guztiz kargatutako egoeratik abiatuta, baterian 10 A-ko deskarga-intentsitatea $(2,87 \mathrm{C})$ aplikatu diogu $200 \mathrm{~s}$-tan zehar. 10 A-ko intentsitatea altua da bateria bakar baterako. Hala ere, MNKE 26650 (3.500 mAh) bateriak 20 A-ko intentsitate onargarri maximoa jasan dezake (pultsuetan $60 \mathrm{~A}-$ raino deskargatu dezake) [31]. Ikerketa honetako simulazio elektrotermiko guztietan, sistema osoaren hasierako tenperatura $26,85^{\circ} \mathrm{C}(300 \mathrm{~K})$ izan da. Deskargaren ostean, bateria \% 80,6ko karga-egoeran dago, eta $43,9^{\circ} \mathrm{C}$-ko tenperatura maximoa dauka. Hau da, deskarga-intentsitate handia denez, bateriaren tenperatura nabarmen igo da, \% 64. Tenperatura nahiko homogeneoa da bateria osoan zehar (ikus 8. irudia), baina bere simetria ardatzean (zilindroaren biraketa-ardatza) gradiente txiki bat azaltzen da. Izan ere, elektrodo positiboaren korronte-kolektorearen mihia da gehien berotzen den bateriako elementua. $20 \mu \mathrm{m}$-ko lodierako korronte-kolektore hori aluminiozkoa da $\left(26,5 \times 10^{-9} \Omega \cdot \mathrm{m}\right.$-ko erresistibitatea). Elektrodo negatiboko korronte-kolektorearen mihia ere berotzen da, baina positiboarena baino 
gutxiago. Beste korronte-kolektore hori kobrezkoa da $\left(16,7 \times 10^{-9} \Omega \cdot \mathrm{m}\right)$, eta meheagoa da, $15 \mu \mathrm{m}$-ko lodierakoa. Berez, aluminioaren erresistibitate elektriko handiagoak eragiten du beroketa-diferentzia hori.

$43,9{ }^{\circ} \mathrm{C}$-ko tenperatura maximoa LMO kimikako baterien ihes-tenperaturatik urrun dago, $250^{\circ} \mathrm{C}$, alegia (ikus 2. taula) $[12,22]$. Ihes-tenperaturara ailegatzean, bateriak kontrolik gabe berotzen jarraituko luke abiadura handiz (nahiz eta zirkuitutik deskonektatu), lehertu arte. Hala ere, gomendatutako $40{ }^{\circ} \mathrm{C}$-ko muga gaindituko luke [13].
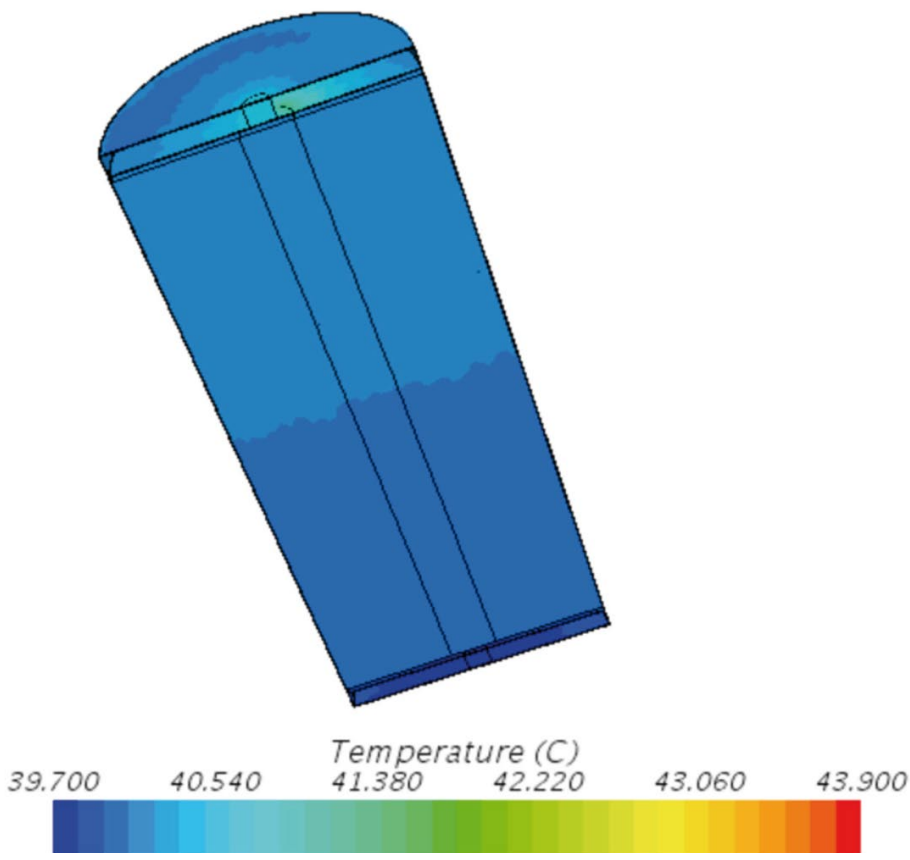

8. irudia. Bateriaren barruko tenperatura-banaketa 10 A-ko deskarga izan ostean (200 s).

\subsection{S5P bateria-multzoa}

Behin bateria bakarraren jokaera aztertuta, LMO kimikadun 26650 bateriekin eraikitako $14 \mathrm{~S} 5 \mathrm{P}$ bateria-multzo osoaren analisi elektrotermikora pasatu gara. Bateria-multzoaren tentsio nominala eta kapazitatea honako hauek dira, 54,74 V eta 17,4 Ah, hurrenez hurren. Hasieran, baterien sigisaga elkarketa baino ez dugu kontuan hartu; hau da, karkasa, airea, BMSa eta lotura elektrikoak baztertu ditugu. Konfigurazio honetan, bateriak birtualki lotuta daude simulazioa burutzeko. 9. irudian bateria-multzoarekin erabilitako kalkulu-sarea ageri da (2.668.416 gelaxka). 
Jose Miguel Campillo-Robles, Iñaki Veci, Josu M. Igartua, Benjamín Ballesteros

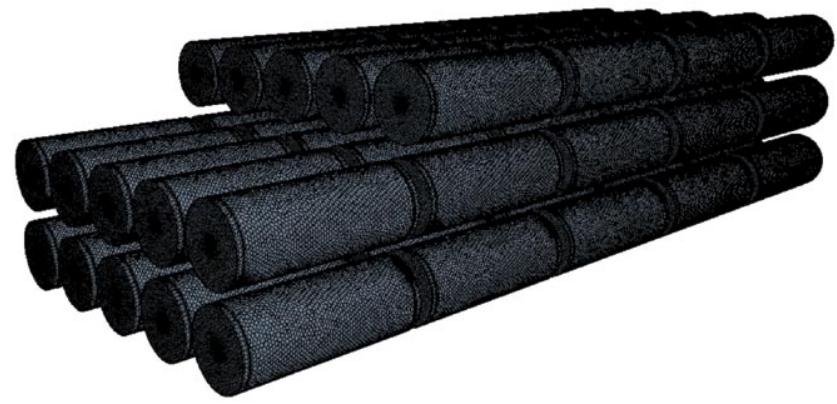

9. irudia. 14S5P bateria-multzoaren kalkulu-sarea.

Simulazioaren hasieran, bateria-multzoaren tenperatura $26,85^{\circ} \mathrm{C}$ da, eta guztiz kargatuta dago. Berriro, $10 \mathrm{~A}$-ko deskarga $(0,57 \mathrm{C})$ eragin dugu 200 s-tan. Deskarga-intentsitate hori ez da handia bateria-multzorako, eta horregatik, lorturiko tenperatura maximoa ez da oso handia, $27,4{ }^{\circ} \mathrm{C}$ (ikus 10.a) irudia). 14S5P bateria-multzoak onartu dezakeen intentsitate maximoa $20 \mathrm{~A}$ da $(1,15 \mathrm{C})$. Intentsitate horrekin bateria-multzoa berriro deskargatu dugu 200 s-tan. Kasu honetan, tenperatura maximoa gehiago handitu da, $28,6^{\circ} \mathrm{C}$-etara (ikus 10. eta 11 . a) irudiak), baina ez bateria bakarraren kasuan bezain beste. 10. a) irudiak erakusten du bateria-multzoaren tenperatura maximoa eta minimoa nola handitzen diren deskargan zehar. 10 eta 20 A-ko deskargetan, bateria-multzoaren karga-egoera \% 96,1 eta \% 92,2ra jaitsi da, hurrenez hurren. 10. b) irudiak erakusten du tentsioaren bilakaera deskarga-prozesu bietan.

a)

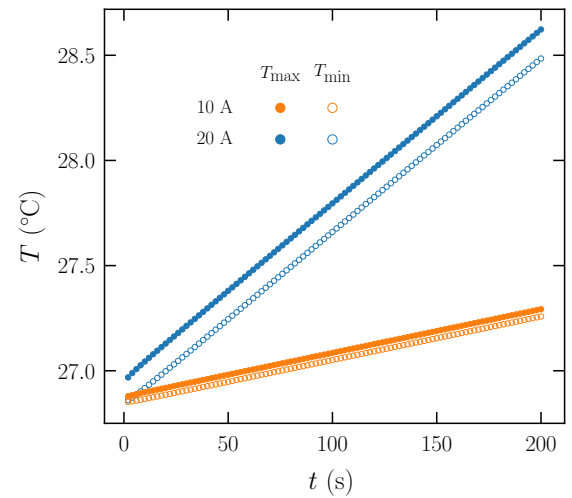

b)

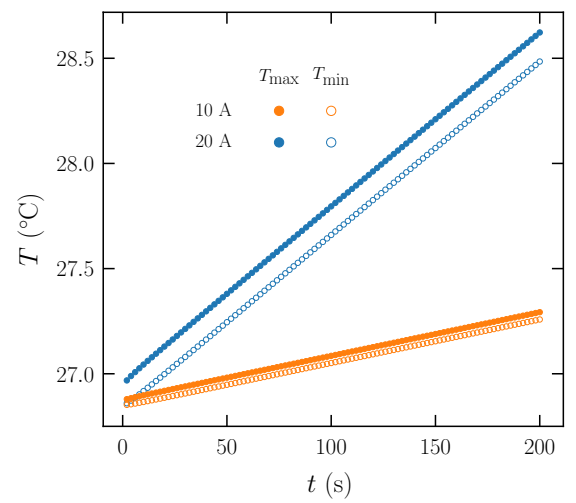

10. irudia. 10 eta 20 A-ko deskargetan, 14S5P bateria-multzoaren: a) tenperatura maximo eta minimoaren bilakaera eta $b$ ) tentsio-aldaketa. 


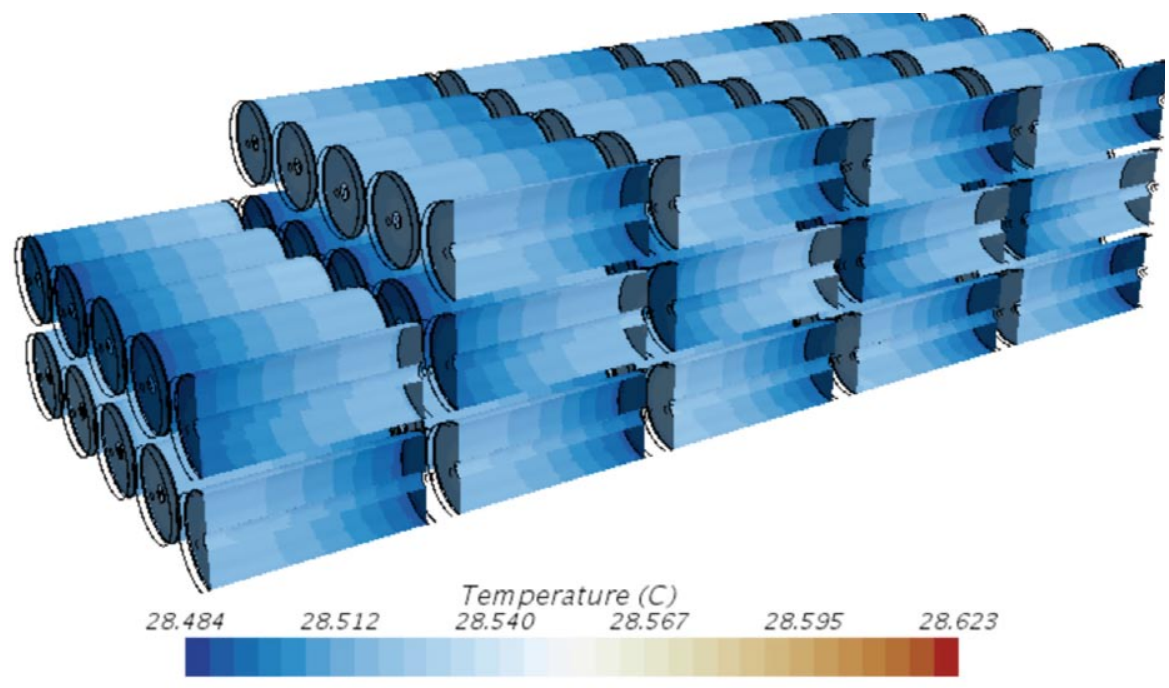

11. irudia. $14 \mathrm{~S} 5 \mathrm{P}$ bateria-multzoaren tenperatura-banaketa $20 \mathrm{~A}-\mathrm{ko}$ deskargaren ostean (200 s).

Aurretik simulatutako 26650 bateria zilindriko bakarrean, tenperaturagradiente axial txiki bat ageri da (ikus 8. irudia). Tenperatura-gradiente hau txikia izanik ere, 14S5P bateria-multzoaren simulazioetan azaltzen da, adibidez, 200 s-ko 20 A-ko deskargan (ikus 11. irudia).

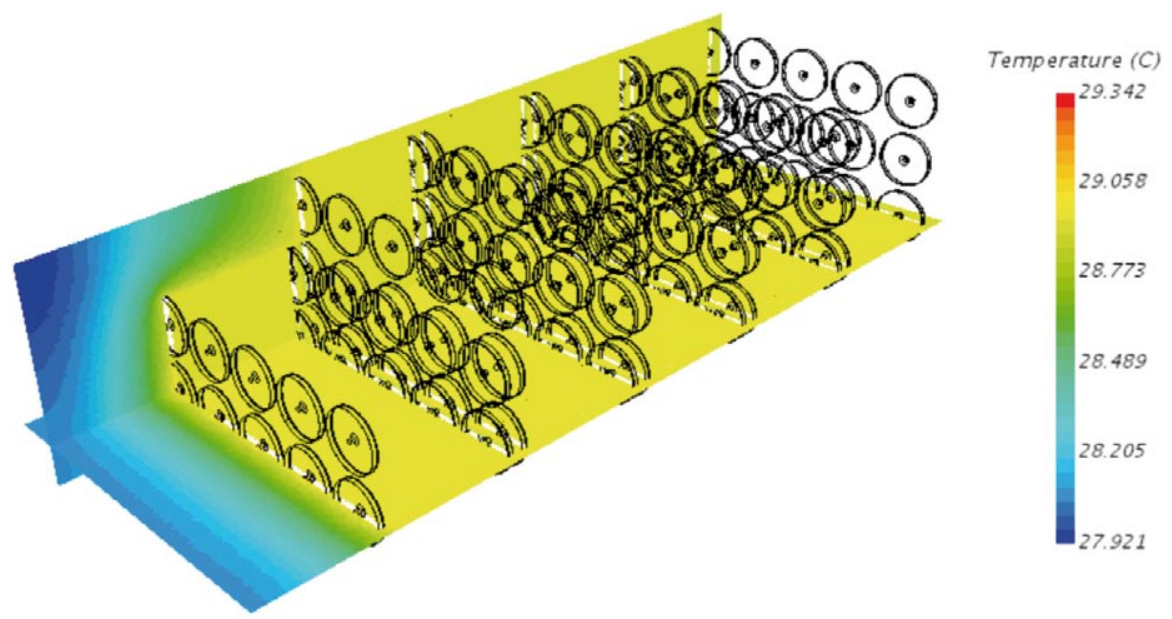

12. irudia. Karkasadun bateria-multzoaren tenperatura-banaketa bi ebaketa axialetan (200 s-ko 20 A-ko deskarga). 
Amaitzeko, karkasaren barruko airea ere kontuan hartu dugu 14S5P bateria-multzoaren simulazio elektrotermikoetan. Karkasa itxiaren dimentsioak honako hauek dira: $409 \times 99 \times 159 \mathrm{~mm}^{3}$ (ikus 4. irudia). Izatez, bateria-multzoaren masa osoa (BMS eta kableak barne) 9,3 kg-koa da. Prozesu elektrikoen hasieran, sistema osoa $26,85{ }^{\circ} \mathrm{C}$-etan dago. Kalkulu-sare berriak 3.988.165 gelaxka ditu, eta bi eskualdetan banaturik dago, alde batetik, bateriak eta, bestetik, kanpoko espazioa (airea). Baterien eskualdea solido modura hartzen da, eta bertan, aurreko kasuetan bezala, soluzio elektrikoa eta termikoa kalkulatzen da era autobateragarri batean. Karkasa eta baterien arteko eskualdea (airea), berriz, fluido modura hartzen da. Bertan, bero-transferentziako ekuazioak ebazten dira, Navier-Stokes-en batez besteko ekuazioak (ingelesez, Reynolds-Averaged Navier-Stokes, RANS), fluxu zurrunbilotsurako k-epsilon ereduarekin. Simulazio multifisikoek erakusten dute karkasadun sisteman tenperatura gehiago handitzen dela, bateriak inguratzen dituen aire-geruzaren eraginez. Adibidez, karkasadun bateria-multzoa 20 A-ko intentsitatearekin deskargatzen badugu 200 s-tan, amaierako karga-egoera eta tentsioa karkasarik gabeko simulazioaren berdinak dira. Bateria-multzoaren tenperatura maximoa hamarren bat besterik ez da igotzen (ikus 12. eta 13. irudiak). Beraz, karkasaren barruko airea simulazioetan sartzeak ez du eragin handirik tenperatura maximoaren kalkuluan, baina baterien inguruko tenperatura-banaketa nolakoa den ikusteko laguntzen du. Hortaz, ohiko lan-baldintzetan, balio onargarrien barruan dago 14S5P bateria-multzoaren tenperatura, eta horregatik, ondoriozta daiteke bateria-multzoaren diseinua egokia dela eta ez duela hozte-mekanismo berezirik behar.
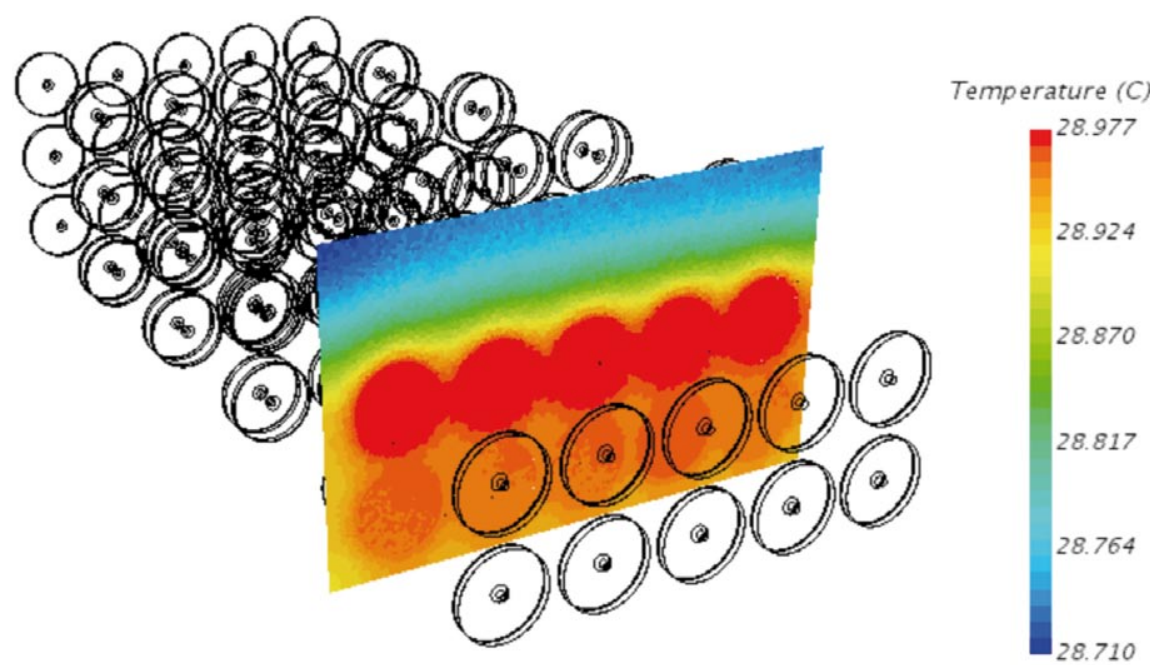

13. irudia. Karkasadun bateria-multzoaren tenperatura-banaketa zeharkako ebaketa batean (200 s-ko 20 A-ko deskarga). 
14S5P bateria-multzoaren simulazio elektrotermiko guztietan, baterien arteko tenperatura-diferentziak $1{ }^{\circ} \mathrm{C}$ baino txikiagoak dira (ikus 12 . eta 13. irudiak). Hots, diferentzia horiek muga onargarrien barruan daude $\left(3-5^{\circ} \mathrm{C}\right)[13,14]$.

\section{ONDORIOAK}

14S5P bateria-multzo komertzialaren lehen eredu multifisikoa garatu dugu bere jokaera elektrotermikoa aztertzeko. Hasteko, LMO kimikadun 26650 bateriaren eredu elektrokimikoak berretsi digu LMO kimikak deskarga-kapazitate txikia duela. Hori hobetzeko, katodoaren material aktiboan NMC sartu ohi da. Hori eginez, LMOko bateriaren ezaugarri elektrikoak nabarmen hobetzen direla frogatu dugu. Ondoren, LMO kimikadun 26650 baterian 10 A-ko deskarga eragitean, tenperatura nabarmen igotzen dela behatu dugu (\% 64). Bestalde, 10 eta 20 A-ko deskargetan, 14S5P bateria-multzoaren tenperatura ez da gehiegi igotzen, gehienez, \% 7. Horrek frogatzen du 14S5P bateria-multzoak era egokian lan egin dezakeela gehiegi berotu gabe. Hau da, ohiko lan-baldintzetarako diseinua egokia du bateria-multzoak, eta ez da hozte aktiboko bestelako elementurik behar.

\section{ESKER ONAK}

Egileek eskertzen dute UPV/EHU-ko IZO-SGI SGIker-en giza laguntza eta babes teknikoa. Bestalde, Rebattery eta Evolo enpresei ere eskerrak eman nahi dizkiegu ikerketa-lan hau aurrera ateratzeko emandako laguntzagatik.

\section{BIBLIOGRAFIA}

[1] GUARNIERI, M. 2012. «Looking back to electric cars». Third IEEE HISTory of ELectro-technology CONference (HISTELCON).

[2] WESTBROOK, M. H. 2001. The Electric Car. Development and future of battery, hybrid and fuel-cell cars. IET Power and Energy Series 38. The Institution of Engineering and Technology, Londres.

[3] RAPIER, R. 2012. Power plays: Energy options in the age of peak oil. Apress, New York.

[4] GATES, J.E., TRAUGER, D.L. eta CZECH, B. (ed.). 2014. Peak Oil, Economic Growth, and Wildlife Conservation. Springer, New York.

[5] Navigant Research. 2016. Electric bicycles li-ion and SLA e-bikes: drivetrain, motor, and battery technology trends, competitive landscape and global market forecasts: https://www.navigantresearch.com/. 
[6] MADUREIRA, N.L. 2014. Key concepts in energy. Elsevier, Heidelberg.

[7] WU, Y. (ed.). 2015. Lithium-ion batteries. Fundamentals and Applications. CRC Press, Boca Raton.

[8] MENICTAS, C., SKYLLAS-KAZACOS, M. eta LIM, T.M. (ed.). 2014. Advances in batteries for medium- and large-scale energy storage. Woodhead Publishing Series in Energy: Number 67, Elsevier, Cambridge.

[9] WARNER, J.T. 2019. Lithium-ion battery chemistries. Elsevier, Amsterdam.

[10] JULIEN, C.M., MAUGER, A., ZAGHIB, K. and GROULT, H. 2014. «Comparative issues of cathode materials for $\mathrm{Li}$-ion batteries». Inorganics $\mathbf{2}$, 132-154.

[11] DOEFF, M.M. Battery Cathods (chapter 2). BRODD, R.J. (ed.). 2013. Batteries for sustainability: Selected entries from the encyclopedia of sustainability science and technology, Springer Science+Business Media, New York.

[12] SAW, L.H., YE, Y. eta TAY, A.A.O. 2016. «Integration issues of lithiumion battery into electric vehicles battery pack». J. Cleaner Production 113, 1032-1045.

[13] RAHN, C.D. and WANG, C.-Y. 2013. Battery systems engineering, John Wiley \& Sons Ltd, Chichester.

[14] DINCER, I., HAMUT, H.S. eta JAVANI, N. 2017. Thermal management of electric vehicle battery systems (Automotive series). John Wiley \& Sons Ltd, Chichester.

[15] CAMPILLO-ROBLES, J.M., VECI, I., DEL TESO SANCHEZ, K. eta CANTERO, I. 2018. «18650 litio-ioi bateriaren jokaera termikoaren analisia». Materialen Zientzia eta Teknologiaren IV. Kongresua (MZT 2018), Lanen Bilduma, 409-414.

[16] DAMBLANC, G., HARTRIDGE, S., SPOTNITZ, R. eta IMAICHI, K. 2011. «Validation of a new simulation tool for the analysis of electrochemical and thermal performance of lithium ion batteries». JSAE Congress.

[17] Evolo Z2 triziklo elektrikoa: http://www.evolo.es/es/z2

[18] Europako Parlamentuko eta Kontseiluaren 2002/24/CE zuzentaraua (2002ko martxoaren 18): https://publications.europa.eu/es/publication-detail/-/ publication/282b266a-d379-4708-aa2c-1971827cc85d/language-en.

[19] ISO 4210:1996 araua. Zikloak - Bizikletentzako segurtasun-baldintzak: https://www.iso.org/standard/10004.html

[20] BERG, H. 2015. Batteries for electric vehicles. Materials and electrochemistry. Cambridge University Press, Cambridge.

[21] WARNER, J. 2015. The handbook of lithium-ion battery pack design: Chemistry, components, types and terminology. Elsevier, Amsterdam.

[22] ZHANG, R., XIA, B., LI, B., CAO, L., LAI, Y., ZHENG, W., WANG, H. eta WANG, W. 2018. «State of the art of lithium-ion battery SOC estimation for electrical vehicles». Energies 11, 1820.

[23] THACKERAY, M.M., DAVID, W.I.F., BRUCE, P.G. and GOODENOUGH, J. B. 1983. «Lithium insertion into manganese spinels». Mater. Res. Bull. 18, 461-472. 
[24] TARASCON, J.M. 2016. «The Li-ion battery: 25 years of exciting and enriching experiences». Electrochem. Soc. Interface 25, 79-83.

[25] SMITH, A.J., SMITH, S.R., BYRNE, T., BURNS, J.C. eta DAHN, J.R. 2012. «Synergies in blended $\mathrm{LiMn}_{2} \mathrm{O}_{4}$ and $\mathrm{Li}\left[\mathrm{Ni}_{1 / 3} \mathrm{Mn}_{1 / 3} \mathrm{Co}_{1 / 3}\right] \mathrm{O}_{2}$ positive electrodes». J. Electrochem. Soc. 159 (10), A1696-A1701.

[26] WANG, J., PUREWAL, J., LIU, P., HICKS-GARNER, J., SOUKIAZIAN, S., SHERMAN, E., SORENSON, A., VU, L., TATARIA, H. eta VERBRUGGE, M.W. 2014. «Degradation of lithium ion batteries employing graphite negatives and nickel-cobalt-manganese oxide + spinel manganese oxide positives: Part 1, aging mechanisms and life estimation». J. Power Sources 269, 937-948.

[27] PUREWAL, J., WANG, J., LIU, P., GRAETZ, J., SOUKIAZIAN, S., TATARIA, H. eta VERBRUGGE, M.W. 2014. «Degradation of lithium ion batteries employing graphite negatives and nickel-cobalt-manganese oxide + spinel manganese oxide positives: Part 2, chemical-mechanical degradation model». J. Power Sources 272, 1154-1161.

[28] MAO, Z., FARKHONDEH, M., PRITZKER, M., FOWLER, M. eta CHEN, Z. 2017. «Charge/discharge asymmetry in blended lithium-ion electrodes». J. Electrochem. Soc. 164 (2), A39-A47.

[29] ZHANG, X. 2011. «Thermal analysis of a cylindrical lithium-ion battery». Electrochim. Acta 56, 1246-1255.

[30] YUAN, C., DENG, Y., TONGHUI, L. eta YANG, F. 2017. «Manufacturing energy analysis of lithium ion battery pack for electric vehicles». CIRP Annals - Manufacturing Technology 66, 53-56.

[31] MNKE 26650 (3500 mAh) bateriaren fitxa teknikoa eta karga-/deskargakurbak: https://www.reddit.com/r/flashlight/comments/2iewjl/battery_test_ mnke_26650_3500mah/.

[32] KASNATSCHEEW, J., PLACKE, T., STREIPERT, B., ROTHERMEL, S., WAGNER, R., MEISTER, P., LASKOVIC, I.C. eta WINTER, M. 2017. «A Tutorial into practical capacity and mass balancing of lithium ion batteries». J. Electrochem. Soc. 164 (12), A2479-A2486.

[33] NEBL, C., STEGER, F. eta SCHWEIGER, H.-G. 2017. «Discharge capacity of energy storages as a function of the discharge current - Expanding Peukert's equation». Int. J. Electrochem. Sci. 12, 4940-4957.

[34] CAMPILLO-ROBLES, J.M., ARTETXE, X., DEL TESO SANCHEZ, K., GUTIERREZ, C., MACICIOR, H., RÖSER, S., WAGNER, R. eta WINTER, M. 2019. «General hybrid asymmetric capacitor model: Validation with a commercial lithium ion capacitor». J. Power Sources 425, 110-120. 